Water Resources \& Ecological Monitoring
TVA/WR/WQ- $-90 / 21$

DE9 1005497

WATER RESOURCES MANACEMENT

\title{
Status of Blue Ridge Reservoir
}

\section{An Overview of Reservoir Conditions}

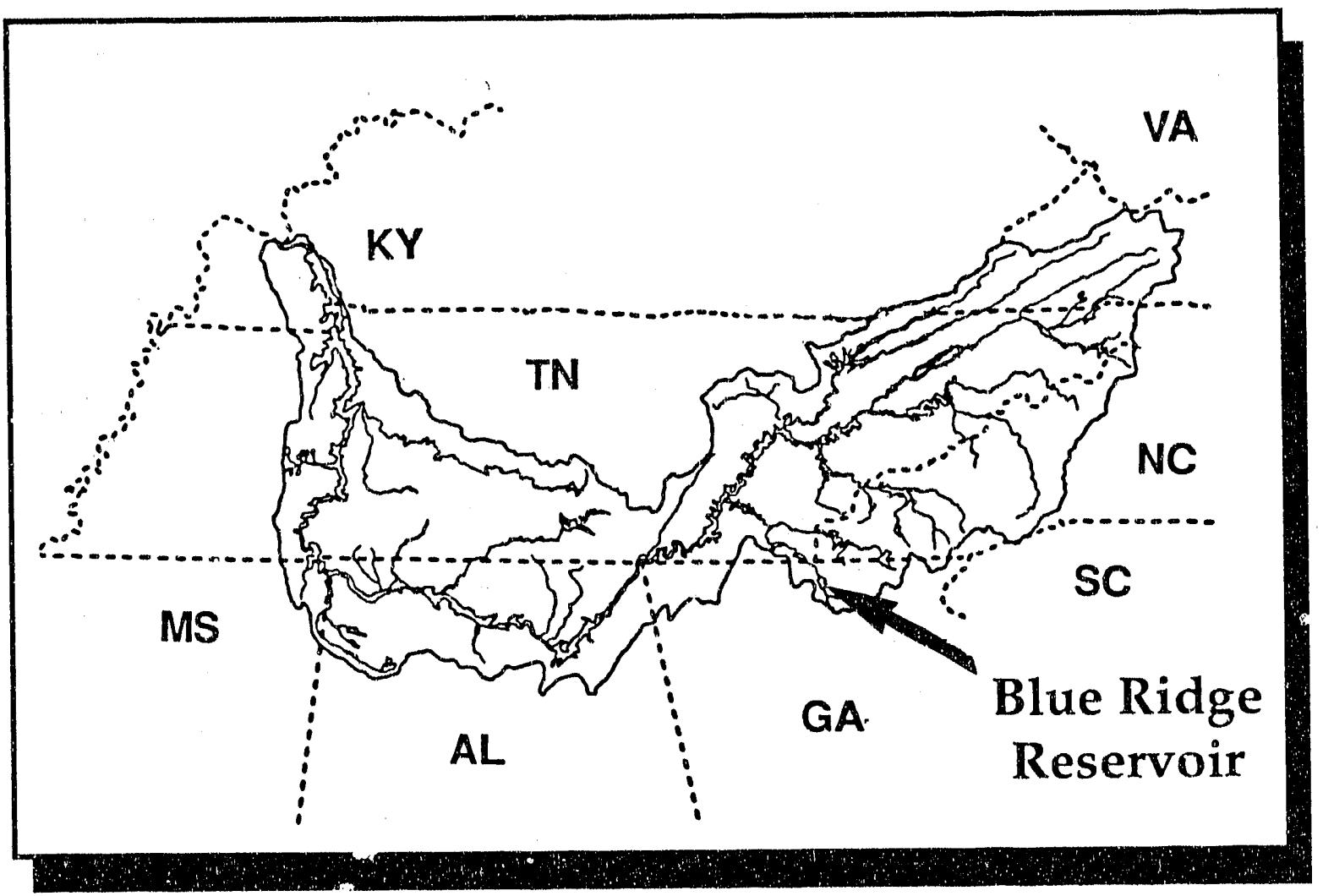

Tennessee Valley Authority

Resource Development

River Basin Operations

Water Resources Division

September 1990 
TVA/WR/WQ--90/21

Tennessee Valley Authority. Water Resources Division.

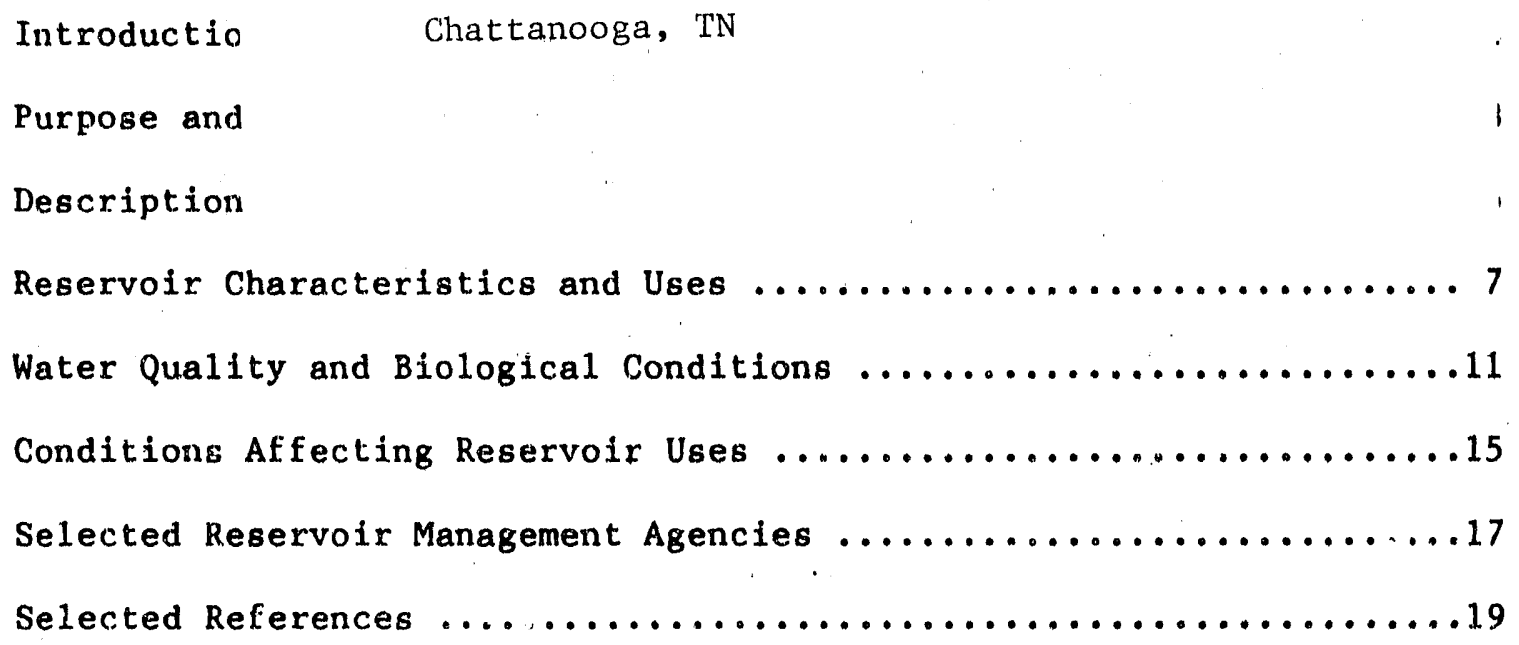

TVA/WR/WQ--90/21 
This is one in a series of reports prepared by the Tennessee Valley Authority (TVA) for those interested in the conditions of TVA reservoirs. This overview of Blue Ridge Reservoir summarizes reservoir and watershed characteristics, reservoir uses and use impairments, water quality and aquatic biological conditions, and activities of reservoir management agencies. This information was extracted from the most current reports and data available, as well as interviews with watcr resource professionals in various federal, state, and local agencies.

Blue Ridge Reservoir is a single-purpose hydropower generating project. When consistent with this primary objective, the reservoir is also operated to benefit secondary objectives including water quality, recreation, fish and aquatic habitat, development of shoreline, aesthetic quality, and other public and private uses that support overall regional economic growth and development.

The water quality of Blue Ridge Reservoir is generally very good. There are no known significant point (pipe discharges) or nonpoint sources of pollution. The reservoir waters are extremely soft, sometimes slightly acidic, and low in plant nutrients. The reservoir fish population is considered "predator heavy" because of a restricted forage base. Smal1mouth bass, wal_eye, and bluegil1 are the species most sought after by anglers, but fishing pressure is low compared to other north Georgia reservoirs.

One of the most significant constraints on use of Blue Ridge Reservoir is the pattern of water level fluctuation resulting from operation for power production. Pool drawdown during the late summer limits access to some boat docks and exposes unvegetated shoreline that detracts from the scenic beauty of the area. Federal ownership of much of the shoreline of the reservoir also limits private development of lakefront property. Presently, the recreational facilities around Blue Ridge are operating at much less than their projected capacity. 
Several agencies play a role in protecting and improving the beneficial uses of the reservoir and in managing day-to-day operations. The agencies most actively involved in managing the resources of Blue Ridge Reservoir are TVA, the U.S. Forest Service, and the Georgia Department of Natural Resources. 
Blue Ridge Dam, built in 1930 by Tennessee Electric Power Company, impounds the Toccoa River from mile 53 to mile 64. TVA purchased the facility in 1939 for the sole purpose of hydropower production. Blue Ridge Dam has one hydropower unit with a generating capacity of 20,000 kilowatts--about 0.6 percent of the total hydropower capacity of the TVA system.

B1ue Ridge Dan is operated to help meet power system demands as economically as possible. Because hydropower generation is the most economical, versatile, and dependable power source in the TVA system, it is used to provide peaking power quickly for those times when daily power demand is highest. Hydropower generation is also scheduled for high demand times of the week (generally during the 5-day workweek) and high demand times of the year (June through August, and December through February).

As a result of hydropower operations, the reservoir pool elevation varies seasonally (see figure on following page). The large amount of water used to generate power during the high power demand summer months causes the pool elevation to drop about 14 feet between April and August and another 23 feet by November. TVA is evaluating the feasibility of extending summer pool elevation through August 1 in Blue Ridge Reservoir (and several other reservoirs) to benefit recreational use.

Blue Ridge Reservoir is not operated to maintain flood storage capacity. However, substantial flood reductions have been achieved in some flood situations because the reservoir elevation happened to be low enough at the time of the flood to permit TVA to store some of the floodwaters.

TVA has informally committed to release water from Blue Ridge Reservoir when needed to provide a minimum flow of $99 \mathrm{it}^{3} / \mathrm{sec}$ at Copperhil1, Tennessee, to meet the water supply needs of Tennessee Chemical Company. 


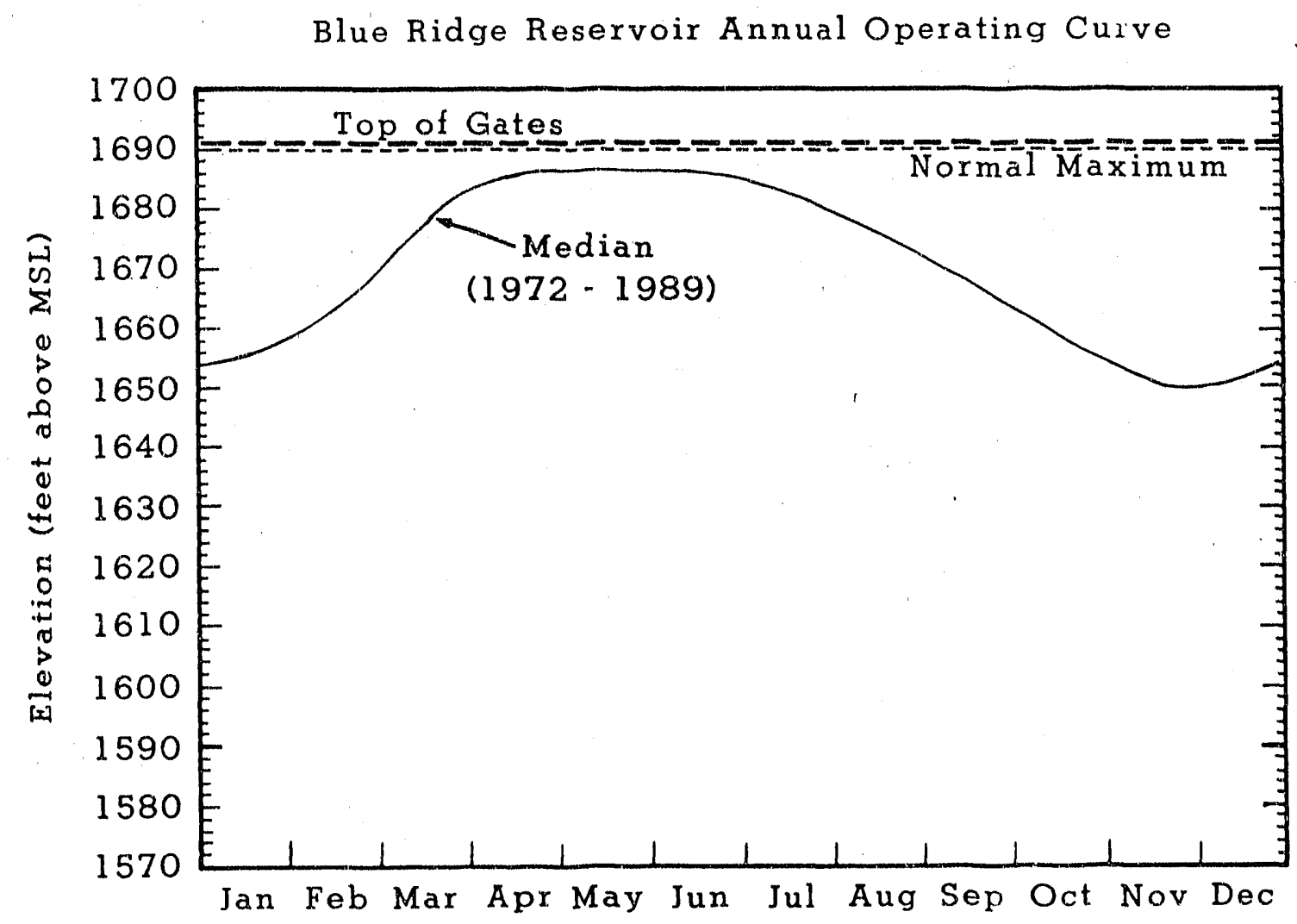


DESCRIPTION OF WATERSHED AND RESERVOIR AREA

\section{Watershed Characteristics}

B1ue Ridge Reservoir lies entirely within Fannin County in northwest Georgia. Fannin County is rural except for four small incorporated municipalities: Blue Ridge, McCaysville, Mineral Bluff, and Morganton. The population of Fannin County is approximately 16,100 (1987 estimate) and growing about 1.3 percent each year. The populations of the cities of Blue Ridge and McCaysville, however, have been declining since 1950. As noted in the 1990 Fannin County Recreation Master Plan, completion of the Appalachian Development Highway is expected to help stabilize population growth by spurring development opportunities and providing a better transportation network for residents who work outside Fannin County.

The per capita income in Fannin County has been estimated at $\$ 9,906$ and is increasing at an annual rate of about 2.4 percent, primarily as a result of recreation, tourism and second home development.

Blue Ridge Reservoir and its 232 square mile watershed lie within the Blue Ridge Physiographic Province, an area of mountainous topography with pine and hardwood forested slopes. The soils throughout most of the watershed are rated "poor" to "unsuited" for agricultural use because of their steep slopes and severe erosion potential. The floodplain areas of the upper Toccoa River and Noontootla Creek (upstream from Blue Ridge Reservoir), contain limited areas of soils suited to cultivation. The principal crop on those lands is corn. The principal livestock operations in the county are pastured beef cattle.

About three-quarters of the population of Fannin County depend on septic tanks for wastewater disposal. The steep slopes that characterize the area make failure of septic systems a relatively common problem.

Homes located near streams or along reservoir shorelines are of particular concern, as failure of their septic systems can degrade water quality. 
About half of Fannin County and a significant proportion of the 232 square miles of Blue Ridge Reservoir watershed lie within Chattahoochee National Forest. About three quarters of the land in the county is commercial forest; logging on private and U.S. Forest Service lands produces about 4.9 million board feet of lumber (primarily hardwood) per year.

\section{Shoreline Characteristics}

Blue Ridge Reservoir has 65 miles of shoreline at full pool; 47 miles are within Chattahoochee National Forest, 3 miles are owned by TVA, and 16 miles are privately owned. Some private homes and cabins already exist on the Forest Service lands, but the Forest Service no longer grants special use permits, so no additional private dwellings can be built on these lands. About half of the privately owned shoreline has been developed. TVA anticipates a moderate rate of development on the remaining private shoreline through the $1990 \mathrm{~s}$. 


\section{Physical Charactexistics}

Blue Ridge Reservoir is small relative to most other TVA reservoirs. When full, it covers about 3200 acres and holds about 8.4 million cubic feet of water. The reservoir has a mean depth of about 60 feet and is over 130 feet deep at the dam. Other physical features of the reservoir are summarized lelow:

\begin{tabular}{lr} 
Feature & Measurement \\
\cline { 2 - 2 } Location, Toccoa River miles & 53 to 64 \\
Norma1 maximum surface elevation, & \\
feet above mean sea leve1 & 1690 \\
$\quad$ Surface area, acres & 3,290 \\
Volume, acre-feet & 193,000 \\
Mean depth, feet & 59 \\
Jength, miles & 11 \\
Shoreline length, miles & 65 \\
Average surface elevation, & \\
feet above mean sea level & 2,670 \\
Surface area, acres & 132,600 \\
Volume, acre-feet & \\
Useful controlled storage volume, & 183,900 \\
acre-feet (elevation 1691-1590) & 109 \\
Average hydraulic retention time, days &
\end{tabular}

\section{Hydrologic Characteristics}

The rate of discharge of water from Blue Ridge Reservoir averages about 605 cubic feet per second ( $\mathrm{cfs}$ ), although there are some days (about 46 days per year, on average) when no water at all is discharged.

Uses of Blue Ridge Reservoir

The principal uses of Blue Ridge Reservoir are for hydropower production and recreation. An estimated 22,000 people visit the reservoir each year between April and 0ctober. Ready access to Atlanta, Georgia, via the Appalachian Development Highway, is expected to increase annual visitation of Blue Ridge to about 25,000. Activities associated 
with the 1996 01ympics, to be hosted by Atlanta, are also expected to increase visitation to the area.

The only public beach on Blue Ridge Reservoir is operated by the U.S. Forest Service at Morganton Point (see centerfold map). There are three pub1ic launch ramps, also maintained by the U.S. Forest Service: Lake Blue Ridge, Morganton Point, and Lakewood Landing. There is one commercial marina (B1ue Ridge Marina) located near the dam. Further development of the shoreline for other purposes (such as second homes or vacation homes) is limited by federal ownership of most of the shoreline. This circumstance is beneficial, however, to the water quality of the reservoir.

There are no water supply intakes or wastewater discharges in the reservoir. The city of Blue Ridge, Georgia, has a water supply intake located immediately downstream from Blue Ridge Dam. 


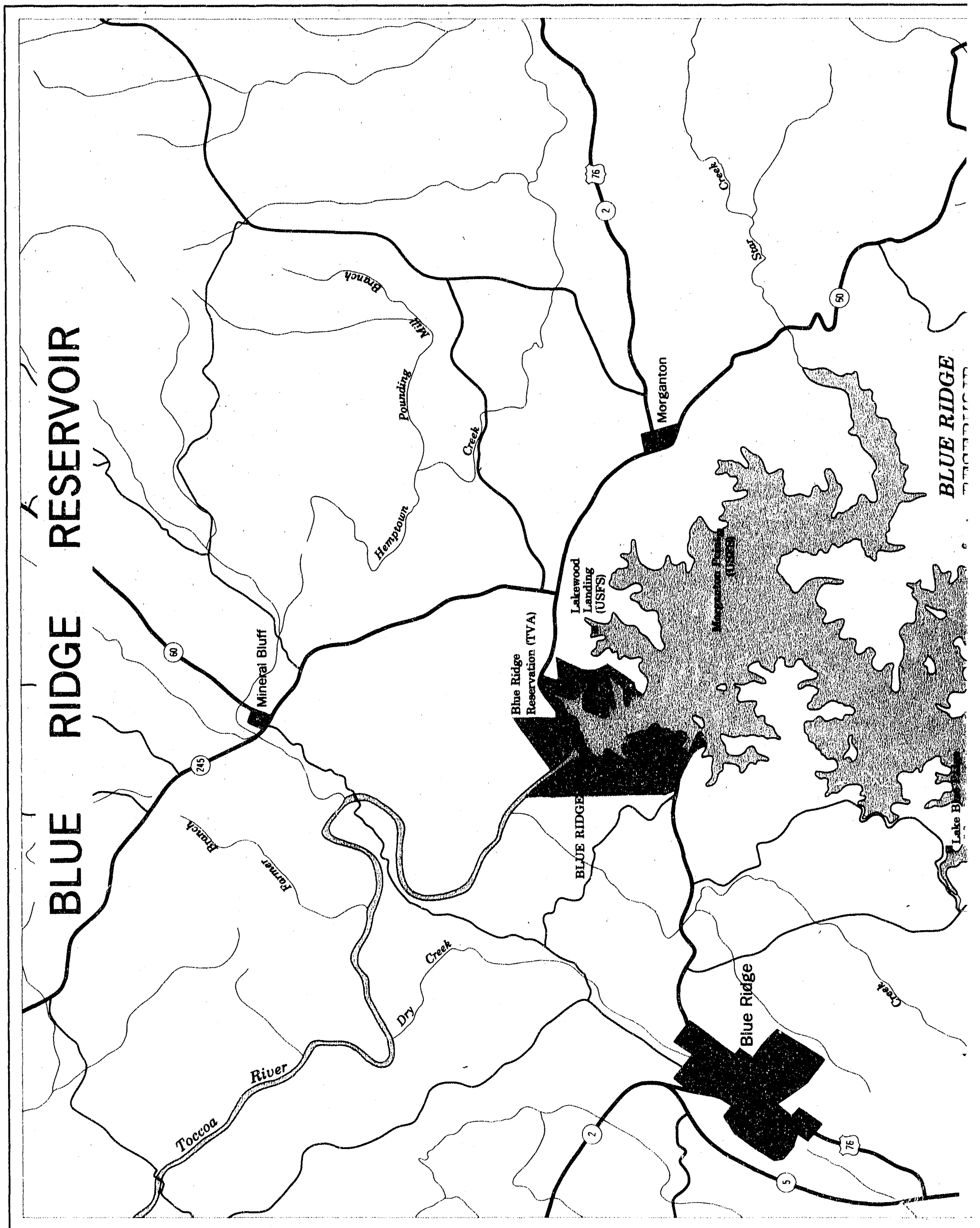




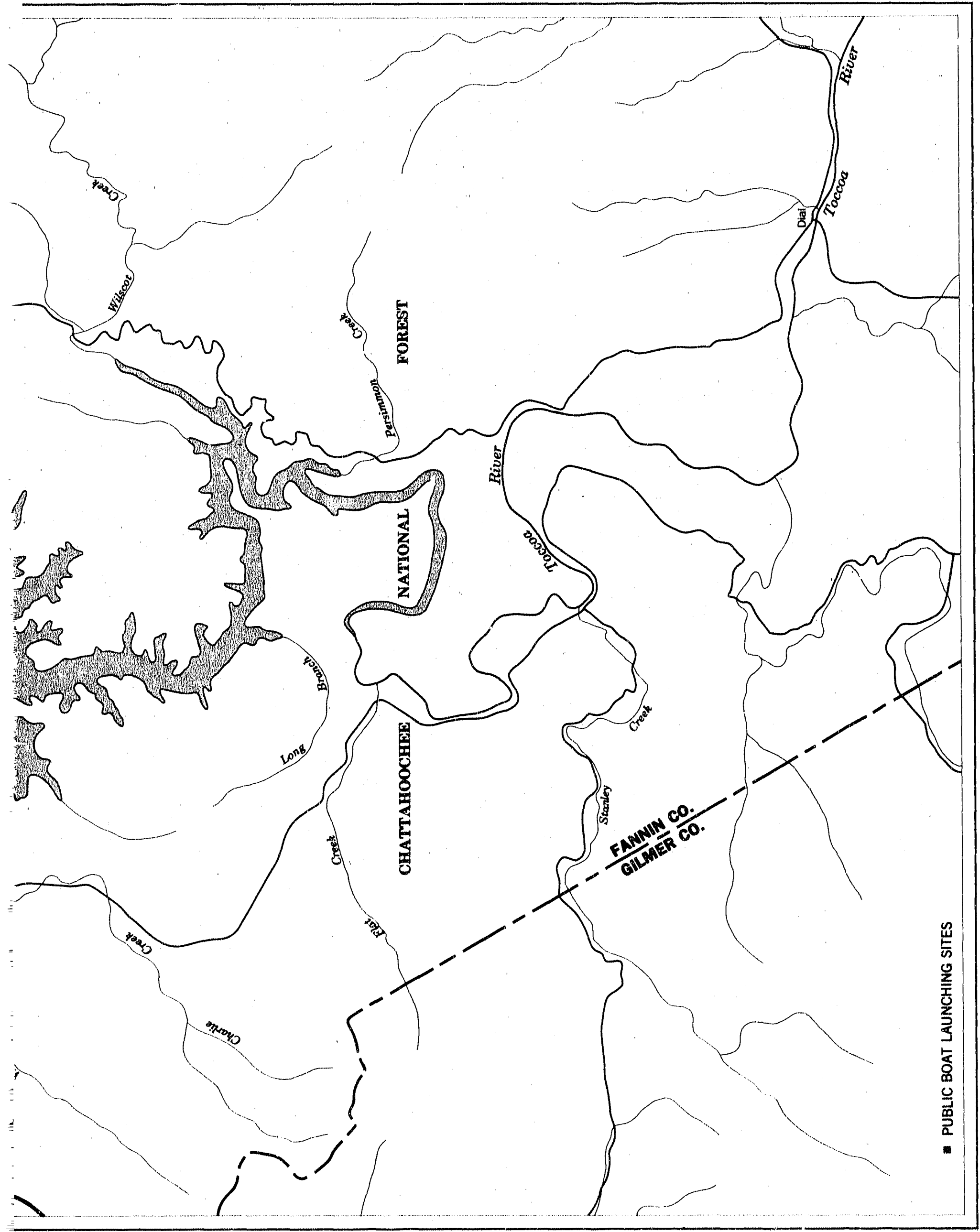


WATER QUALITY AND BIOLOGICAL CONDITIONS

Chemical Characteristics

The water quality of Blue Ridge Reservoir strongly reflects the nature of its watershed: primarily undisturbed, forested lands underlain by metamorphic and igneous rocks. The water is somewhat acidic (mean pH $6.2)$, very soft (mean hardness less than 10 milligrams per 1 iter $(\mathrm{mg} / 1)$ and poorly buffered (mean alkalinity less than $5 \mathrm{mg} / 1$ ). Total dissolved solids and conductivity are also very low (1ess than $20 \mathrm{mg} / 1$ and less than 20 micromhos $(\mathrm{cm}$, resyectively). There are no recent data on the turbidity o: the water that flows into the reservoir, but water in the reservoir itself tends to be very clesr (mean Secchi depth over 7 feet; mean turbidity 1.7 Nephelometric turbidity inits).

Temperature and Dissolved Oxysen

Like most of TVA's tributary reservoirs, Blue $R$ "dge Reservoir becomes thermally stratified in sumer. In early spring the sun warms the surface waters more rapidly than the ceeper waters, separating the reservoir into two relatively distinct layers of different temperature. During the sumer, temperature in the upper layer reaches a maximum of about $82^{\circ} \mathrm{F}$, while the temperature in the bottom layer stays about $68^{\circ} \mathrm{F}$ or lower. The depth of the thermocline (the boundary between the two layers) varies from 10 to 25 feet. Thermal stratification continues until the surface waters cool in the auturm and the entire water column begins to mix ("turns over"). The precise time when the water column begins to mix again depends primarily on the weather, especially air temperature, rainfall, and wind. Following "turnover," the water colum tends to remain mixed throughout the winter until spring, when the thermal stratification cycle begins anew.

During thernal stratification, algal photosynthesis in the sunlit upper layer of water produces oxygen, raises the $\mathrm{pH}$ to neutral (7.0) or higher, and $f$ oduces the organic matter that provides the basis of the aquatic food chrin. The organic material from aquatic organisms eventually settles and decays in the lower layer of water, using up the 
dissolved oxygen. Because the water passed through the turbines in the dam is drawn from deep in the reservoir, water discharged from the reservoir is low in dissolved sxygen during the period of thermal stratification. For about 11 weeks a year, the dissolved oxygen concentration in the discharge is less than the $6.0-\mathrm{mg} / 1$ state criterion for trout streams. In recent years, the minimum dissolved oxygen ( $r$ hich usually occurs in september) has been about $3.0 \mathrm{mg} / 1$. The temperature of the water released is also a concen for the tailwater fishery; the water released is normally cold enough for trout, but during periods when there is no discharge, the tailwater becomes warmer than desired for trout $\left(68^{\circ} \mathrm{F}\right)$.

\section{Bacteriological Water Quality}

The bacteriological quality of Blue Ridge Reservoir is excellent. The U.S. Forest Service regularly monitors the concentration of fecal coliform bacteria at Morganton Point beach to confirm that the wat ar quality is suitable for swimming.

\section{Trophic Status}

Average concentrations of the plant nutrients nitrogen and phosphorus are low in Blue R:.dge Reservoir $(0.55 \mathrm{mg} / \mathrm{L}$ nitrogen and less than 0.01 $\mathrm{mg} / 1$ phosphorus); coneequently, phytoplankton (microscopic algae) populations tend tu be sparse. In this reservoir, the low concentration of nitrogen (which declires throughout the summer as it is taken up by phytoplankton) seems to be a more important limiting factor than the low concentration of phosphorus. The aquatic ecosystem responds to this by favoring the development of algae that are able to "fix" nitrogen--that is, to convert nitrogen gas from the atmosphere into organic nitrogen. However, even when the demand for nitrogen is met, the low levels of phosphorus 1 imit further development of algae. Consequently, Blue Ridge Reservoir is considered "oligotrophic"--at the opposite end of the spectrum from highly productive or "eutrophic" reservoirs. 


\section{Aquatic Organisms}

Information describing individual components of the biological community of Blue Riage Reservoir (zooplankton, benthos, mussels) is limited or nonexistent. However, the relative infertility of the reselvoir is clearly reflected at the top of the aquatic food chain by the unproductive fishery. As is typical of many mountain reservoirs, the standing stock of fish is low and dominated by predator (game) fish. The following table compares biomass in pounds per acre of game, rough, and forage fishes in Blue Ridge Reservoir with other tributary reservoirs of the Tennessee River system.

\begin{tabular}{|c|c|c|c|c|c|c|c|}
\hline \multirow[b]{2}{*}{ Reservoir } & \multirow[b]{2}{*}{ Inclusive } & \multirow[b]{2}{*}{ Dates } & \multirow{2}{*}{$\begin{array}{c}\text { Number of } \\
\text { samples }\end{array}$} & \multicolumn{4}{|c|}{ Biomass $(1 \mathrm{~b} / \mathrm{ac})$} \\
\hline & & & & Game & Fough & Forage & Tota1 \\
\hline Cherokee & $1949-$ & -1989 & 106 & 69 & 113 & 507 & 789 \\
\hline Boone & $1953-$ & -1983 & 31 & 51 & 58 & 245 & 354 \\
\hline Melton Hill & 1964 & -1982 & 45 & 20 & 152 & 126 & 298 \\
\hline South Holston & $1951-$ & -1985 & 45 & 58 & 62 & 161 & 2.81 \\
\hline Te11ico & 1980 & - 1981 & 4 & 46 & 113 & 108 & 267 \\
\hline Douglas & $1949-$ & -1983 & 37. & 47 & 103 & 53 & 203 \\
\hline Ft. Patrick Henry & ry 1954 & -1985 & 8 & 19 & 69 & 57 & 145 \\
\hline Watauga & 1949 & -1984 & 38 & 44 & 38 & 57 & 139 \\
\hline Thorpe & $1952-$ & -1965 & 6 & 43 & $<1$ & 74 & 117 \\
\hline Norris & $1949-$ & -1.989 & 101 & 31 & 27 & 108 & 116 \\
\hline Nottely & $1958-$ & -1970 & 14 & 44 & 39 & 23 & 106 \\
\hline Fontana & $1949-$ & -1984 & 22 & 35 & 30 & 32 & 97 \\
\hline Blue Ridge & 1958 & -1963 & 11 & 37 & 25 & 15 & 77 \\
\hline Cheoah & 1952 & -1965 & 3 & 16 & 49 & 3 & 67 \\
\hline Appalachia & 1952 & -1983 & 6 & 16 & 16 & 27 & 60 \\
\hline Chatuge & 1953 & -1980 & 18 & 42 & 9 & 7 & 58 \\
\hline Santeet $1 \mathrm{ah}$ & 1949 & -1965 & 11 & 29 & 7 & 18 & 55 \\
\hline Parksville & 1951 & - 1970 & 12 & 6 & 11 & $<1$ & 18 \\
\hline Nantahala & & 1952 & 1 & 15 & 0 & 0 & 15 \\
\hline
\end{tabular}

Twenty-two species of fishes are known to occur in Blue Ridge Reservoir. The principai game species are smallmouth bass, 1 argemouth bass, and walleye. Although gizzard shad are present in the reservoir, their population is small and made up primarily of large adults. The gizzard shad population is kept at low levels by the infertility of the water and the relatively high number of predator $\mathrm{fish}$ in the reservoir. Periodic stocking of additional prey (threadfin shad) to augment the forage base has resulted in little apparent success. 
Bluegill and whitetail shiners were the most common $f$ ish species taken in 1988 in electrofishing samples, followed by smallmouth bass, redbreast sunfish, largemouth bass, green sunfish, and yellow perch. Neither gizzard shad nor threadfin shad were collected in these samples. Capture rates for largemouth bass, smallmouth bass, and waileye were below historical catch rates for other North Carolina and Georgia storage reservoirs in the TVA system. Mo t of the sunfish were sma11, ranging in length from 2 to 6 inches, making them of 1ittle value to sport fishermen. Although not abundant, some largemouth bass of desir ble size were collected. Smallmouth bass were most abundant in the 4 to 5 -inch size range, but ranged up to 13 inches in length.

Smallmouth bass, walleye, and bluegill are the species most sought after by anglers, but fishing pressure on Blue Ridge Reservoir is low compared to other north Georgia reservoirs. There is also a sporadic crappie fishery in the reservoir, and a seasonal white bass fishery exists during spawning migrations in the headwater reaches of the Toccoa River.

The low standing crop of fish composed primarily of game fish is 1 ikely to continue in Blue Ridge Reservoir because the reservoir is infertile and consequent 1 y supports only a limited forage base. This condition is not expected to change under present $f$ sheries management procedures. To improve angling success, TVA has installed numerous fish attractors in coves of Blue Ridge Reservoir. TVA and the U.S. Forest Service have also seeded some shoreline with reed canary grass to offset the lack of natural cover for the fish.

\section{Threatened and Endangered Species}

There are no federally listed threatened or endangered species reported from the reservoir. However, a lamprey (mountain brook lamprey) and four fish species (river redhorse, blotched chub, telescope shiner, and tangerine darter) listed by Georgia with a "Special Concern" status occur in the Blue Ridge area. Only the tangerine darter has been collected from the reservoir. The river redhorse occurs in the Blue Ridge tailwaters. The other three species are found in the Toccoa River and its tributaries. 
CONDITIONS AFFECTING RESERVOIR USE

The principal uses of Blue Ridge Reservoir are hydropower production and recreation. There are no significant water quality problems that impact these uses. Existing water quality is adequate to support additional uses (such as water supply) that are not presently in demand.

Natural circumstances or conditions resulting from the location and operation of the reservoir have both positive and negative effects on its use. The cool, clear waters of this mountain reservoir are we11-suited to such recreational uses as swimming and skiing, and the mountainous backdrop provides an aesthetic quality to the area--especially when the reservoir is ful1. Pool drawdowns for hydropower production expose the unvegetated shoreline ("bathtub ring"), which detracts from the scenic beauty of the area and also limits access to boat docks.

The unpolluted nature of the water is also reflected in the biotic community. As a natural consequence of its relatively pristine watershed, Blue Ridge Reservoir has low concentrations of plant nutrients and therefore does not provide a food base adequate to support a well-balanced fish community. Blue Ridge has a low biomass of fish, which is typical of mountainous headwater tributary reservoirs of the Tennessee River System. This makes the reservoir "difficult to fish," which is reflected in lower fishing pressure on Blue Ridge than on other north Georgia and North Carolina tributary reservoirs.

Although there is relatively little oxygen-demanding material in the water, the depth of the reservoir, its relatively long detention time, and the location of the power intake deep in the reservoir result in a discharge that is cold and has low concentrations of dissolved oxygen. These factors, along with the intermittent nature of the discharges, adversely affect aquatic life in the tailwater. 
The conditions affecting the uses of Blue Ridge Reservoir are summarized as follows:

Condition

Runoff from pristine watershed is low in nutrients

Pool drawdown for hydropower production

Intermittent discharge of water with low dissolved oxygen and low temperature

$$
\text { Use (s) affected }
$$

o Water tends to be clear and aesthetically pleasing

n Fish community is "predator heavy" and fishing pressure is low.

- Unvegtated shoreline ("bath tub ring") detracts from scenic beauty.

- Limits access to some boat docks.

- Adversely affects aquatic 1ife in tailwater. 
Severa1 agencies have a role in investigation and monitoring of the reservoir. A number of those agencies are 1 isted below. They provide information and assistarce geared to the varying needs of the region they serve.

The Tennessee Valley Authority Water Resources Division manages the daily operation of Blue Ridge Rescrvoir, conducts water quality and aquatic resource monitoring and assessment programs, and develops plans for protecting and enhancing water resources. The Land Resources Division manages TVA lands along the reservoirs and monitors the status of threatened and endangered species in the area.

Tennessee Valley Authority

Water Resources Division

Evans Building

Room 1W 141A

Knoxville, Tennessee 37902-1499

Phone: (615) $-632-6770$

The U.S. Forest Service manages the lands and streams in

Torest and maintains Forest Service recreation facilities in the area.

\author{
U.S. Forest Service \\ Toccoa Ranger District \\ Route 3, Box 3222 \\ B1ue Ridge, Georgia 30513 \\ Phone: $\quad(404)-632-3031$
}

The Georgia Department of Natural Resources is the primary environmental regulatory agency in Georgia. The Environmenta1 Protection Division determines water use classifications, criteria and standards, and issues permits for wastewater discharges. It also regulates water supplies, solid and hazardous waste, and air quality. The vorth Georgia regional of fice in Atlanta has primary responsibility for activities in Fannin County.

Environmental Protection Division 19 Martin Luther King Junior Drive Room 435 Atlanta, Georgia 30334

Phone: (404)-656-6300 
The Game and Fish Division of the Georgia Department of Natural Resources is responsible for fish and game regulations, fish stocking, and boating regulations.

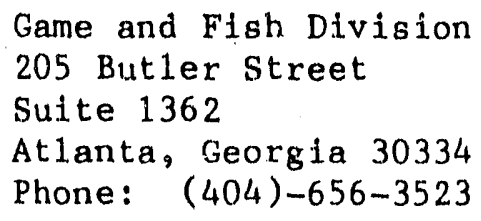

The U.S. Environmental Protection Agency is responsible for implementation of the Clean Water Act and oversees federally mandated programs managed by the states.

U.S. Environmenta1 Protection Agency 345 Court land Street, NE Atlanta, Georgia 30365

Phone: (615) $-347-5242$

The U.S. Fish and Wildife Service is responstble for ensuring the protection of fish and wildife and their habitats during federally sponsored or permitted development activities and has responsibility for the identification of threatened and endangered species.

\author{
U.S. Fish and Wildife Service \\ Federal Building, Room 334 \\ 801 Gloucester Street \\ Brunswick, Georgia 31520 \\ Phone: (912)-265-9336
}




\section{SELECTED REFERENCES}

Colwe11, S. and D. Hi11. No date. The Fishery Resource of Tennessee Valley Tailwaters - Blue Ridge. Tennessee Valley Authority, Division of Water Resources.

Cox, J. 1990. Water Resources Issues Analysis: Hiwassee River Watershed. Tennessee Valley Authority, Division of Water Resources, TVA/WR/WQ $-90 / 3$.

North Georgia Regional Development Center. 1990. Fannin County Recreation Master Plan. Fannin County Recreation Commission, P-89-01-24-201.

$01 \mathrm{em}$, H. 1985. Acidification Trends in Surface Waters of the Southern Appalachians. Tennessee Valley Authority, Division of Air and Water Resources, TVA/ONRED/AWR-85/13.

Placke, J. 1983. Trophic Status Evaluation of TVA Reservoirs. Tennessee Valley Authority, Division of Water Resources, TVA/ONR/WR-83/7.

Tennessee Valley Authority. 1989. TVA Reservoir Biomonitoring Program Fish Populations: Results of 1988 Survey. Tennessee Valley Authority, System Engineering.

Tennessee Va1ley Authority. 1990. Tennessee River and Reservoir System Ojeration and Planning Review, draft Environmental Impact statement.

Zeller, H. and B. McDonald. 1988. Estimated Economic Impact of Accessib ${ }^{1} e$, Stable Lake Leve1s in North Georgia: Lake Blue Ridge, Lake Nottely, Lake Chatuge. Submitted to TVA by the Georgia Department of Natural Resources and the University of Georgia. 
This work was funded by Federal eppropriations to the Tennessee Valley Authority (TVA; for water resources management. This report was prepared by nembers of a project team of the Water Resources Division of TVA with other TVA staff assisting.

Your comments and suggestions are important to us! They help us better meet the information needs of reservoir users. Comments, suggestions, and requests for additional copies of this report should be directed to:

\author{
Larry R. Clark \\ Water Quality Department \\ Tennessee Valley Authority \\ Haney Building, Room 2S $270 \mathrm{C}$ \\ 311 Broad street \\ Chat tanooga, Tennessee 37402-2801 \\ Phone: (615) 751-7331
}

TVA is an equal opportunity and affirmative action employer. TVA also ensures that the benefits of programs receiving TVA financial assistance are available to all eligible persons regardless of race, color, sex, national origin, handicap, or age. 

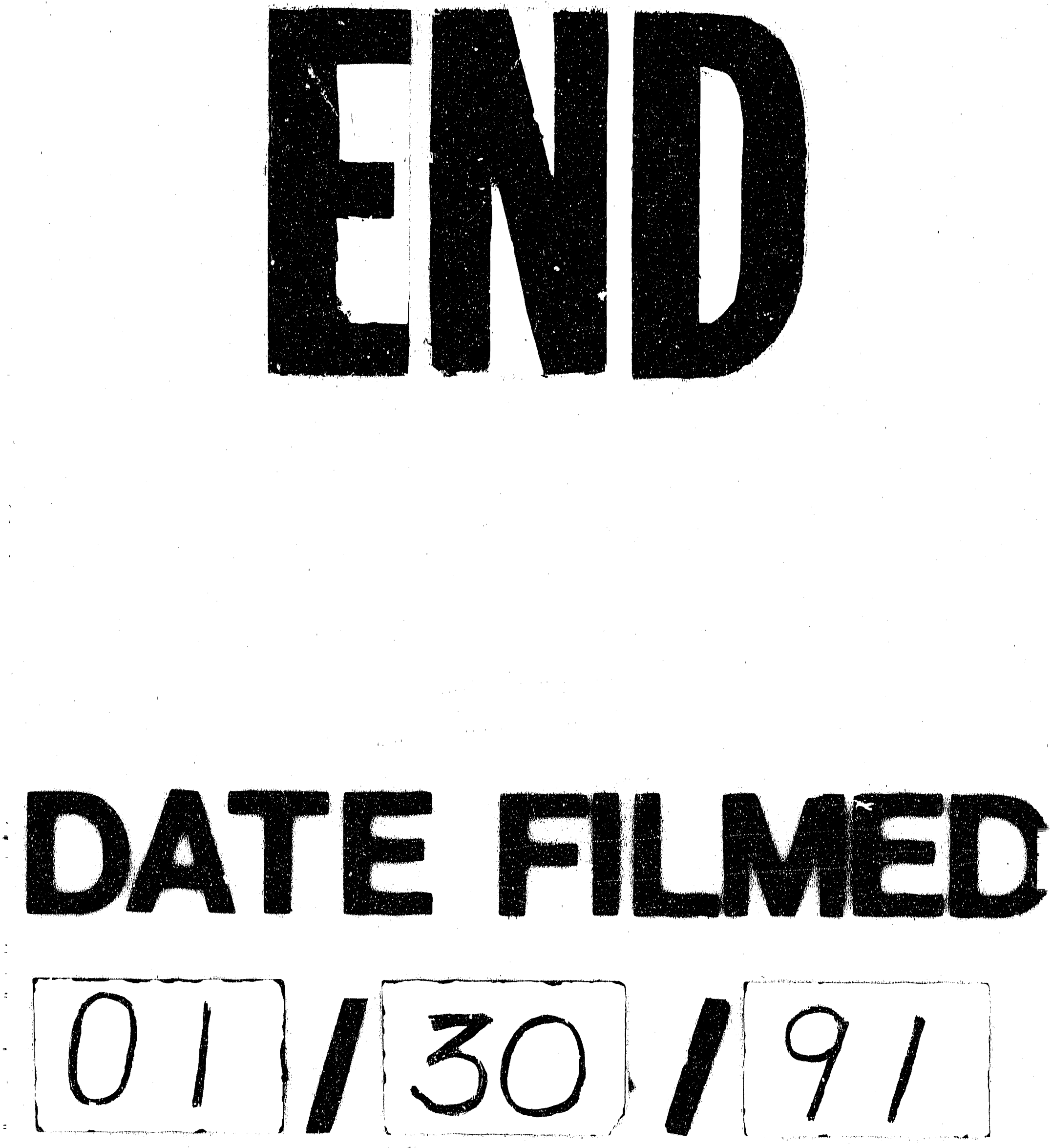
